IZA DP No. 5243

Corruption as a Barrier to Entry: Theory and Evidence

Nauro F. Campos

Saul Estrin

Eugenio Proto

October 2010 


\title{
Corruption as a Barrier to Entry: Theory and Evidence
}

\author{
Nauro F. Campos \\ Brunel University, \\ CEPR and IZA \\ Saul Estrin \\ London School of Economics, \\ CEPR and IZA
}

Eugenio Proto
University of Warwick

Discussion Paper No. 5243

October 2010

\author{
IZA \\ P.O. Box 7240 \\ 53072 Bonn \\ Germany \\ Phone: +49-228-3894-0 \\ Fax: +49-228-3894-180 \\ E-mail: iza@iza.org
}

Any opinions expressed here are those of the author(s) and not those of IZA. Research published in this series may include views on policy, but the institute itself takes no institutional policy positions.

The Institute for the Study of Labor (IZA) in Bonn is a local and virtual international research center and a place of communication between science, politics and business. IZA is an independent nonprofit organization supported by Deutsche Post Foundation. The center is associated with the University of Bonn and offers a stimulating research environment through its international network, workshops and conferences, data service, project support, research visits and doctoral program. IZA engages in (i) original and internationally competitive research in all fields of labor economics, (ii) development of policy concepts, and (iii) dissemination of research results and concepts to the interested public.

IZA Discussion Papers often represent preliminary work and are circulated to encourage discussion. Citation of such a paper should account for its provisional character. A revised version may be available directly from the author. 


\section{ABSTRACT \\ Corruption as a Barrier to Entry: Theory and Evidence ${ }^{*}$}

Conventional wisdom depicts corruption as a tax on incumbent firms. This paper challenges this view in two ways. First, by arguing that corruption matters not so much because of the value of the bribe ("tax"), but because of another less studied feature of corruption, namely bribe unavoidability. Second, we argue that the social costs of corruption arise not because corruption hurts incumbent firms, but mostly because it acts as a powerful barrier to the entry of new firms. Corruption sands and greases in tandem: it helps incumbent firms (on balance) and it hurts potential entrants. We put forward a model in which a bureaucrat chooses entry barriers to optimize bribe revenues. When the capacity to collect bribes is high, it is optimal to allow high levels of oligopoly power to incumbents. Conversely, the more avoidable are the bribes, the more firms are allowed into the market. These ideas are tested using a unique, representative sample of Brazilian manufacturing firms. Consistently with our theoretical model, we show that corruption (a) is ranked as the most important barrier to entry (above finance, taxes and regulation) and (b) while bribes' unavoidability is positively related to firm performance, the size of the bribe is not.

JEL Classification: O12, D23, K20, O17, K30

Keywords: corruption, barriers to entry, firm performance

Corresponding author:

Nauro F. Campos

Department of Economics and Finance

Brunel University (West London)

Uxbridge UB8 3PH

United Kingdom

E-mail: nauro.campos@brunel.ac.uk

\footnotetext{
* We thank Chris Woodruff for comments on a previous draft and are grateful to the Centre for New and Emerging Markets (CNEM) at the London Business School and to the UK's Department for International Development for financial support (2004-2006). We are, of course, responsible for all remaining errors.
} 


\title{
1 Introduction
}

\author{
Capitalism takes no prisoners and kills \\ competition when it can - Vince Cable MP
}

There is a large literature on the causes and effects of corruption, surveyed for example in Bardhan (1997), Aidt (2003, 2009), Svensson (2005), Treisman (2007) and Pande (2008). Corruption is normally conceived as having a negative effect on economic performance. For instance, Mauro (1995) views it as a tax on investment while Goulder et al (1997) suggest bribes may substitute for taxes, thereby reducing public service provision. It is also sometimes argued that bribery "greases the wheels of growth", i.e. it partially addresses inefficiencies created by government intervention (Leff, 1964; Lui, 1985; Meon and Sekkat, 2005) although the econometric evidence supporting a negative effect is overwhelming. The empirical literature identifies significant strong negative relationships between corruption, on the one hand, and income, growth and democracy, on the other (Paldan, 2002; Rose-Ackerman, 1998; Mauro, 1995). However, the exact mechanisms through which the harmful effect of corruption operate on enterprise and national economic performance are still not well understood.

In this paper, we propose and provide supporting evidence for a mechanism that has received little attention so far in the literature, namely that corruption represents an important barrier for new firms, thereby harmfully enhancing the monopoly power and rents earned by incumbent firms. ${ }^{1}$ Following the seminal work of de Soto on legal barriers to entrepreneurship (de Soto, 1990), considerable research has gone into understanding and measuring entry barriers (Djankov et al, 2002) and corruption (Kaufman et al, 2005). This paper takes the analysis a step forward by endogenizing these barriers; in particular we show that when there are little chance of avoiding to pay the bribe and when the bribe collection happens regularly and frequently, namely when the corruption system is effective, incumbent firms tend to perform better. This happens because a profit maximizing bureaucrat will prefer in this case to give more oligopoly power to incumbent firms by allowing fewer new firms into the market. On the other hand, in a system where actors have a good chance to avoid paying bribes, a bureaucrat will prefer to share the risk across firms and will allow more firms into the market. Our model formalises these notions.

The notion that the level of entry barriers represented by corruption is endogenously determined is a crucial step forward in the general debate on whether corruption is a mechanism that "greases" or "sands" the wheels of growth. Our model

\footnotetext{
${ }^{1}$ The literature recognises the important role that new firm entry plays in disseminating information (Acs, 2006) and in transferring resources from low to high value uses (Bertelsman, Haltiwanger and Scarpetta, 2004). Moreover, entry is identified as of particular importance to the development process in e g. Tybout (2000) and the literature has associated cross-country variation in entry rates with the institutional context, including corruption (e.g. Klapper, Laeven, Rajan, 2006).
} 
shows how corruption can be both a "wheel greaser" for incumbent firm and a "wheel sander", for a potential entrant; and that corruption sands the wheels in order to be able to grease the wheels. The implication is that the negative effect should be judged on the basis of the failure to create an optimal level of competition, which is consistent with most of the literature identifying a negative association between corruption and income (Paldam, 2002; Rose-Ackerman, 1998).

The positive relationship between profits and corruption has been emphasized by Johnson, McMillan and Woodruff (2002) and Shleifer and Vishy (2003). There are as yet no empirical studies related to bribe variability and avoidability though a recent theoretical paper by Aidt and Dutta (2008) is linked to ours in that they show how democratic politicians have an incentive to create barriers to entry for new firms via corruption. There are also parallels with Barron and Olken (2009) which analyzes how market forces shapes the mechanism of corruption, as in the present paper, they emphasize an economic rationale behind the mechanisms of bribe formation. The effect of market forces on corruption is also analyzed in Bliss and Di Tella (1997) and Aides and Di Tella (1999), where the causal link goes from market competition to corruption, rather than the converse as in the present paper. ${ }^{2}$

Using our dataset we test these predictions showing that the bribe avoidability is significantly and negatively related to the performance of incumbent firms. Also consistently with the model, we find that in markets where bribes are perceived as more unavoidable, the age of the firm is negatively correlated with performance, as we would expect in protected markets in which older and more technologically obsolete firms thrive.

The dataset developed for this paper is unique in at least three ways. ${ }^{3}$ Firstly, the survey comprises questions which are specifically about firm entry and not exclusively about firm growth. Secondly, the questionnaire was applied to domestic industrial firms, not to foreign investors, or legal specialists or lawyers. ${ }^{4}$ Thirdly, the survey asks not only which are the main obstacles to entry, but also provides an extensive characterization of each. Thus it goes beyond assessing how important an obstacle corruption is to potential entrants to enquire in addition about which aspects of corruption are deemed more or less significant. For example, it contains information about the relative impact of the size of the average bribe against the uncertainty surrounding the need to pay. There is now a literature on regulatory barriers to entry in developing countries based on survey evidence (e.g. Moreira, 1999, Djankov et

\footnotetext{
${ }^{2}$ There is finally a large literature on property rights and corruption in incomplete information framework Rose-Ackerman (1975), Besley and McLaren (1993), Mookherjee and Png (1994), Carrillo (1996), Banerjee (1997), Hindriks et al. (1998), Acemoglu and Verdier (1998) among others.

${ }^{3}$ The survey was conducetd by a established, well-known private consultancy firm in Brazil. Datametrica (at www.datametrica.com.br) has branches and teams throughout the country and specialises in large dedicated surveys to international organisations, and to large private and public firms. We provide further details of this survey in section 3 below.

${ }^{4}$ Although for many issues this may be an inconsequential distinction, that does not seem to be the case when measuring corrution, as shown by Razafindrakoto and Roubaud (2010).
} 
al., 2002; Svensson, 2003; Aterido et al., 2007; ). Most of the existing work assumes that (a) the factors determining the performance of industrial firms coincide with those that impede the entrance of new firms ${ }^{5}$ and (b) that this information can be reliably obtained from foreign investors and/or lawyers. ${ }^{6}$ Our research strategy differs from these previous efforts in that we ask incumbent firms what they consider to be the obstacles or barriers that are most severe to potential entrants. Ours is, to the best of our knowledge, the only survey that asks "which factor is the most important constraint to a new firm that is considering to start production (entry) in your industrial sector?"

The paper is organized as follows. In the next section, we outline the theoretical model. Section 3 presents the dedicated survey we carried out for this paper. Section 4 analyses the most salient data issues. Our data show that corruption is often ranked as the most important barrier to entry (more important than finance, taxes and regulation) and unavoidability is positively associated with firm performance. Section 5 presents the econometric results and we conclude in Section 6.

\section{Theoretical framework}

We present here a simple model, showing how uncertainty in the capacity of the corruptor to collect the bribe and/or the possibility for the firm to avoid paying the bribe is not necessarily good for the incumbent firm itself and might actually result in lower profitability.

There is a market with $N$ identical potential risk neutral firms, and a risk averse bureaucrat, with utility $u(x)$, where $u^{\prime}>0>u^{\prime \prime}$ who determines the number of firms, $n$, permitted to enter the market. ${ }^{7}$

\footnotetext{
${ }^{5}$ In our survey, $70 \%$ of the respondents claim that corruption is a major obstacle to firm entry while only about $30 \%$ claim that corruption was a major obstacle to firm growth in 2000 . This suggests a stark distinction between how incumbent firms view the role of corruption with respect to growth and entry. Corruption is crucial as a mechanism to deter entry of new competitors but only of marginal significance with respect to the operation and growth of incumbent firms.

${ }^{6}$ Thus, the surveys upon which these papers are based are directed either to foreign investors (because they would be able to compare these barriers with those in their countries of origin) or to law firms in developing countries (because they possess detailed knowledge of such barriers). While both are valuable ways of collecting information, they also have weaknesses. Foreign investors are not subject to the same set of constraints, finance for example, as domestic firms and lawyers know more about de jure than de facto barriers.

${ }^{7}$ The fact that there is only one bureaucrat with the power of allowing the firm in a market is somewhat simplistic. In reality the firm has to face permissions from different bodies. However, assuming that there are more than one bureaucrat to seek permission for would not change or results as long as the burocrats are not competimg among each other; i.e. if each of them has the monopoly on one particular concession.
} 
Assume that each firm faces a linear market demand for the good supplied, with an inverse function

$$
p\left(y_{1}, . ., y_{n}\right)=1-\sum_{i=1}^{n} y_{i}
$$

and each firm $i$, produces $y_{i}$ at the cost $c y_{i}$. Firms in the market are assumed to produce in Cournot oligopoly and each maximize

$$
\pi(n)=\max _{y_{i}} p\left(y_{1}, . . y_{i}, . ., y_{n}\right) y_{i}-c y_{i} .
$$

Recalling that firms are symmetric and defining $\bar{y}$ as the quantity produced by each one of the other firms, the solution of problem 1 determines the reaction function for firm i:

$$
y_{i}^{r}=\frac{1-c-(n-1) \bar{y}}{2} .
$$

After production, the bureaucrat is able to extract a proportion of the profit as a bribe. This depends on each firm's and bureaucrat's bargaining power, which we assume to be uncertain ex-ante. As a result the bribe, in terms of share of profits, is represented by a random discrete variable, $\alpha$; we assume that this can be "high", $\bar{\alpha}$, with probability $(1-q)$ or "low", $\underline{\alpha}$, with probability $q$, with $\bar{\alpha}>\underline{\alpha} \geq 0$ and $q>0$.

The probability $q$ is a measure of the avoidability. of paying the bribe, hence $q$ is also a measure of the effectiveness of the bribery system.

We then summarize the timing of the game is as follows:

1. The bureaucrat decides $n \leq N$

2. The incumbent firm $i$ produce $y_{i}$

3. The level of $\alpha$ is known

4. The bribe is paid.

\subsection{Equilibrium}

From 2 , by solving the equation $y_{i}^{r}=\bar{y}$, we obtain the optimal quantity produced by the incumbent firms,

$$
y(n)=\frac{1-c}{1+n},
$$

and their respective profits

$$
\pi(n)=\left(\frac{1-c}{1+n}\right)^{2}
$$


Accordingly the objective function for the bureaucrat is

$$
B(n)=\sum_{i=0}^{n}\left(\begin{array}{c}
n \\
i
\end{array}\right) q^{i}(1-q)^{n-i} u((i \bar{\alpha}+(n-i) \underline{\alpha}) \pi(n)),
$$

and $\mathrm{s} /$ he will choose $n$ to maximize $B(n)$.

Using the bureaucrat objective function (5), we will argue that the optimal number of incumbent firms, $n^{*}$, is non-decreasing in uncertainty $q$. In the case of a risk-neutral bureaucrat, the objective function (5) simplifies to

$$
\frac{(1-c)^{2} n \frac{1}{q}^{n} q^{n}(\bar{\alpha}(1-q)+\underline{\alpha} q)}{(1+n)^{2}}
$$

which is monotonically decreasing in $n$ for $n>1 .^{8}$ Therefore a risk-neutral bureaucrat will always prefer a monopoly, $n^{*}=1$ for any level of $q$. An infinitely risk-averse bureaucrat would only care about the worst state of the world, i.e. when he can only collect $\underline{\alpha}$ from every firm and so will seek the maximum level of diversification with $n=N .^{\frac{9}{}}$ A moderately risk-averse bureaucrat would prefer to diversify risk to some extent, so possibly $n<N$. In this case, the higher is $q$, the greater will be the number of firms with which the bureaucrat prefers to deal. From the expression (4), we can see the the profits of the incumbent firms are decreasing with the number of the firms in the market, $n$. Hence, a higher level of uncertainty $q$ in the bribe collection will result in a lower level of profits, before the bribe, for the firm. We present below an example with $N=2$, to show that the net effect of the lower profits and the higher bribe, may result in a lower level of firm profits after the bribes.

\section{$2.2 \quad$ A Two Firm Example}

In order to have a closed solution and to analyze the net effect of bribes on the industrial organization and firms' profits, we simplify the model by assuming that potential entrants $N=2$. Moreover, for expositional simplicity, we assume that the utility function for the bureaucrat is $u(x)=\sqrt{x}$ and $\underline{\alpha}=0$.

From (3) and (4) by setting $n=2$, we obtain

$$
y(1)=\frac{1-c}{3}
$$

and

$$
\pi(2)=\frac{(1-c)^{2}}{9}
$$

\footnotetext{
${ }^{8}$ Its derivative with respect to $\mathrm{n}$ can be written in the form $g(c, q, n)(1-n)$, where $g(c, q, n)$ is a strictly positive function.

${ }^{9}$ This would imply an total amount of bribe exactly equal to $n(\bar{\alpha}(1-q)+\underline{\alpha} q)$ for $N \rightarrow \infty$.
} 


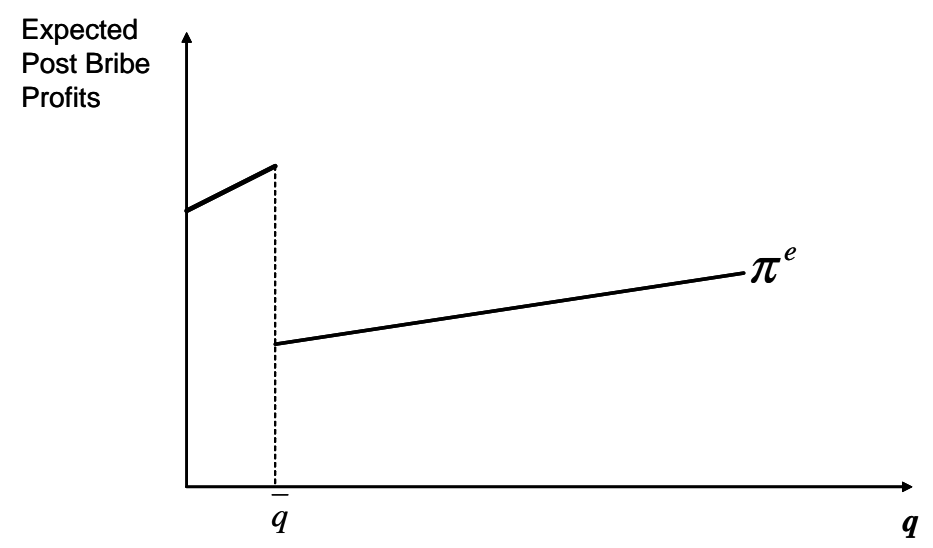

Figure 1: Firms Profits and Bribe Avoidability

while in condition of monopoly, with $n=1$, a firm will make profit:

$$
\pi(1)=\frac{(1-c)^{2}}{4}
$$

The expected utility for a bureaucrat when $n=2$, is

$$
B(2)=(1-q)^{2} \sqrt{\frac{2 \bar{\alpha}}{9}}+2 q(1-q) \sqrt{\frac{\bar{\alpha}}{9}}
$$

while for $n=1$,

$$
B(1)=(1-q) \sqrt{\frac{\bar{\alpha}}{4}}
$$

with $B(1)>B(2)$, when $q<\bar{q} \equiv \frac{3-2 \sqrt{2}}{4-2 \sqrt{2}} \simeq 0.15$.

Accordingly if uncertainty about the bribe increases (i.e. $q$ increases) the bureaucrat prefers to let the second firm enter the market. The expected profits after bribe for the firm, $\hat{\pi}^{e}$, are characterized by the following function

$$
\hat{\pi}^{e}(q)=\begin{array}{ll}
((1-q)(1-\bar{\alpha})+q) \frac{\bar{\alpha}}{4} & q<\bar{q}(\text { where } n=1) \\
((1-q)(1-\bar{\alpha})+q) \frac{\alpha}{9} & q>\bar{q}(\text { where } n=2)
\end{array} .
$$

Figure 1, plots the after-bribe expected profits against bribe uncertainty. We note that profits when uncertainty is low $(q<\bar{q})$ are generally higher than when the uncertainty is high (this is always true whenever $\alpha<\frac{5}{9}$ ).

Finally notice that when, as in this last example, $\underline{\alpha}=0$, we can interpret $1-q$ as a measure of the bribes' frequency, so that we can argue that with high bribe frequency (when $q$ is close to 0) it is plausible to expect high profits.

To summarize the findings of this model we have: 
- Post-bribe profits will decrease with bribe uncertainty or avoidability

- Post-bribe profits will increase with bribe frequency

We can summarize the above points by saying that a more effective system of corruption will ensure higher post-bribe profits to the firm. This is one way in which corruption can work as an effective barrier to the creation and survival of new firms. In the next section, we will provide empirical evidence in support of these propositions.

\section{Data collection}

The two main objectives of this section are to present the survey and sampling design and to provide details on the sample representativeness.

The dataset contains unique survey information collected through face-to-face interviews with CEOs of a representative sample of firms operating in large emerging market (Brazil.) The survey was undertaken by a private firm ${ }^{10}$, and comprised interviews with the CEOs of 98 firms; 28 from the consumer electronics sector and 70 from the textile sector. The interviews were carried out between December 2004 and July 2005 and lasted an average of 90 minutes. The sample was designed to be representative of the two sectors in terms of firm size (number of employees as well as revenue.) There was also concern about the spatial distribution, driven by the expectation that those located in the richer Southeast region would benefit from better physical and service infrastructure and other sources of agglomeration economies. As a consequence, the sampling procedure followed the distribution by region and firm size of the Labor Ministry's RAIS (a dataset containing all registered, that is formal, firms in the country).

Previous studies have usually been carried out at the country level. One important reason for focusing on individual manufacturing sectors is that this identifies the precise industries in consideration when asking about entry. The choice of sectors is very important. One main consideration was to try to focus on two manufacturing sectors that were different in terms of their technological base but whose firms tend to use production technologies that are similarly mature in the sense that these technologies would present barriers to entry of similar nature and magnitude. With this in mind, two sectors were selected at ISIC 3-digit level: within industry code 17 ("manufacture of textiles") and industry code 32 ("manufacture of radio, television and communication equipment"), firms were sampled from those operating in sector 17.1 ("spinning, weaving and finishing of textiles") or in sector 32.3 ("manufacture of television and radio receivers, sound or video recording.") These two sectors (hereafter "textiles" and "consumer electronics," respectively) were chosen because they are both important within their two-digit sectors (in shares in output and employment) and they are

\footnotetext{
${ }^{10}$ More information at Datametrica (at www.datametrica.com.br)
} 
both capital intensive, relatively concentrated, and technologically mature. Further, final users include both industrial firms and households. Finally, and no less importantly, in these two industries the importance of informal sector considerations seems satisfactorily remote. Because RAIS preserves the anonymity of the firms, once the sectors were selected, a representative sample of firms was drawn from a firm (not plant) register at the main industrialists' association in Brazil (FIESP).

The average textile firm in the sample employed 73 full-time workers in 2005, which is close to the corresponding figure for the population of about 64 employees in the 2002 RAIS data. The textile firms in the sample export on average $15 \%$ of the value of their output, compared to $11 \%$ in the population. In terms of destination of these exports, more than $75 \%$ of them are for Mercosul countries, mostly to Argentina, by far the largest destination market. The average age of the firms in the sample is approximately 29 years, raging from 3 to 133 years of continuous operation (see Table 1). The average electronics firm in the sample employed approximately 80 full-time workers in 2005, somewhat below the population average for 2002 of about 130 . The firms in the sample exported approximately $10 \%$ of their output, compared to $8 \%$ in the population. Although a larger average share of output is exported in textiles than in electronics, the percentage of firms that are involved in exporting activities is higher in electronics than textiles. Finally, about $20 \%$ of the electronics firms in the sample have some foreign ownership, against below $5 \%$ for textiles. These figures are similar to data from the late 1990s (Moreira, 1999).

\section{Data analysis}

What are the main lessons one learns from these new data? One of the central questions of the survey is about predominant barriers to entry. CEOs were presented with a list of potential factors and asked to identify which was the most important entry barrier at the time of the survey as well as 5 and 10 years before (i.e., for years 2005, 2000 and 1995 respectively). As shown in Table 2, the list of factors is exhaustive and includes the availability of finance, corruption, quality of the transport and communications infrastructure, and taxation. Table 2 displays a summary of survey responses. The main finding is that approximately 70 percent of the firms in the sample identified corruption as the most important barrier to a firm that was considering entry in year 2005. The relevant figures for years 2000 and 1995 are not very different from the ones for 2005 suggesting that CEOs not only view corruption as the main barrier to entry, but also that they see it as persistent, remaining the most important barrier to entry during the previous ten years. Also notice that the importance attached to corruption seems to have varied little between 1995 and 2005. This is even more remarkable in light of the substantial changes in the relative importance of other factors that our surveys depicts: focusing on the top 5 factors, since 1995 the relative importance of two decreased (policy uncertainty and lack 
of skilled labour), while the relative importance of the other two factors increased (finance and taxes). It should also be mentioned that interviewed were presented with a list of 15 factors with corruption listed as item number 9 (it was placed about the middle of the list, rather than at the beginning or the end).

Are barriers to the growth of incumbent firms different from barriers to the entry of new firms? Over the last ten years, there has been a rapid expansion of firm-level survey evidence on barriers to growth and since the focus of such surveys was the "climate for investment" and "difficulties in doing business", the overlap between the two sets of barriers was implied. However, whether or not they are the same is an empirical question. In this respect it is instructive to compare the responses to our survey to firm-level survey The World Bank conducted in 1999 (an Investment Climate Assessment) covering 201 Brazilian firms. ${ }^{11}$ The type of question in the surveys is similar and there is one question that almost perfectly overlaps, asking whether or not the firm perceives a series of factors as a major obstacle to growth. Figure 1 contrasts the results from the two surveys (we report the answers for year 2000 for barriers to entry so as to make it more easily comparable to the World Bank data). It shows that taxes and regulations are perceived by CEOs to be the major obstacle to operation and growth of firms in Brazil in the late 1990s with $71.6 \%$ of them arguing that this item is a major obstacle. The second most important factor is the instability and uncertainty surrounding government policy, followed by exchange rate instability, crime and public safety matters, and availability of finance. Only about $30 \%$ of the respondents claim that corruption was a major obstacle to firm growth in 2000, while about $70 \%$ of the firms in our survey claim that corruption is a major obstacle to firm entry $^{12}$. This suggests a stark distinction between how incumbent firms view the role of corruption with respect to growth and entry. Corruption is crucial as a mechanism to deter entry of new competitors but only of marginal significance with respect to the operation and growth of incumbent firms. This suggests that incumbent firms support a stark distinction on the effectiveness with which corruption plays a role.

The questionnaire permits a fine characterization of the economic mechanisms triggered by corruption, it contains further questions on three dimensions of corruption: the size of the bribe (how much it would cost to the firm in management time and in monetary terms), the frequency of the bribe, and the avoidability. of the bribe. ${ }^{13}$ The bottom panel of Table 1 presents the relevant statistics. The average

\footnotetext{
${ }^{11}$ Two important differences that should be kept in mind when comapring these two sets of reponses are that The World Bank sample is larger than ours and it includes firms from all industrial and service sectors.

${ }^{12}$ Figure 1 shows comparable information between our data set and the World Bank survey. It refers to "among these barriers, which one is the major obstacle?" Table 2 presents answers to a different question, namely "which is the most important barrier at the time of the survey, as well as 5 and 10 years before?" The latter information is not available in the World Bank data so it is impossible to directly compare ours to it.

${ }^{13}$ The question on "avoidability" was phrased: "how often is it true that if a public official act in an irregular manner, your firm can contact his or her superior (or another public official) and receive
} 


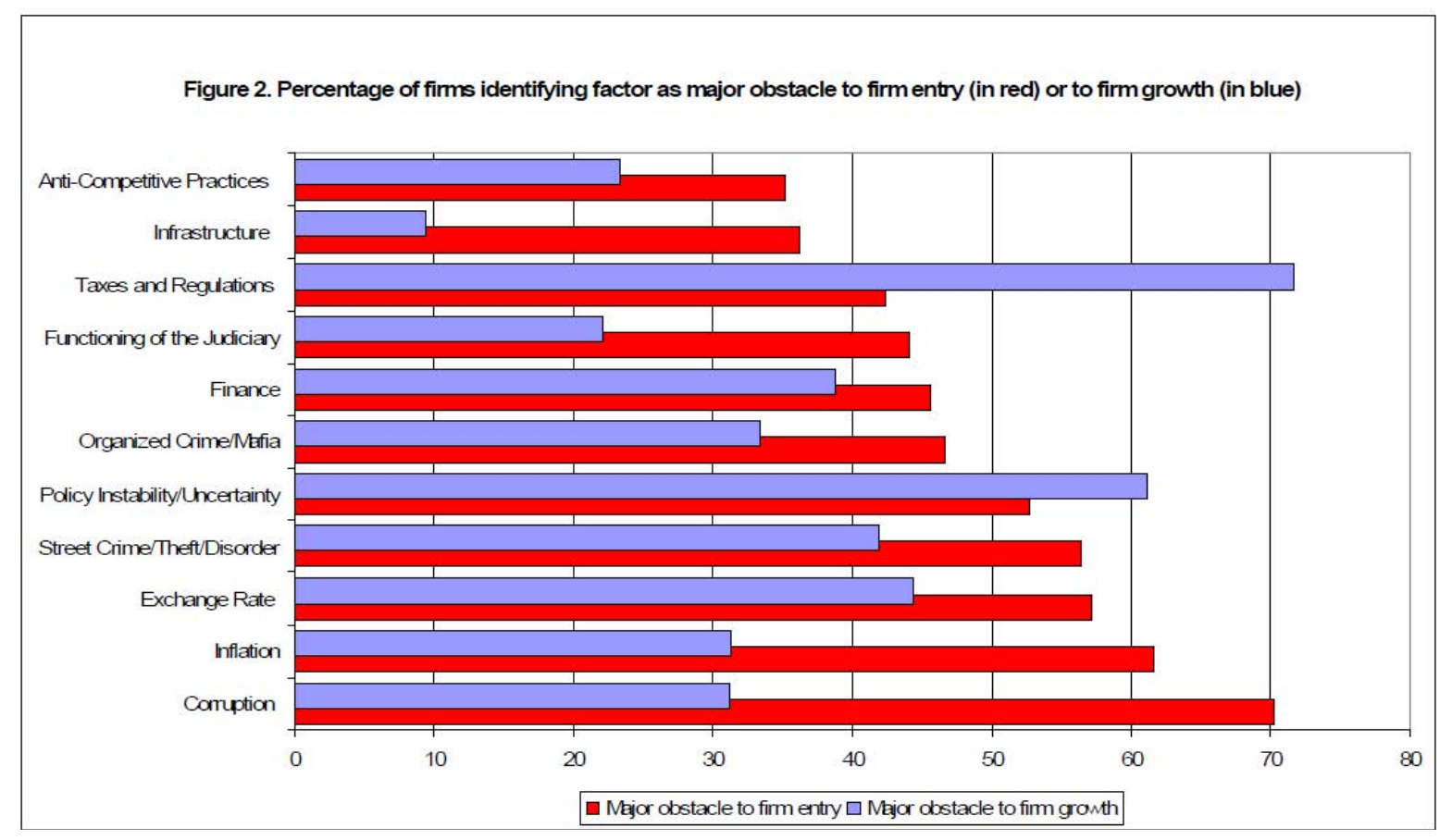

size of the bribe, expressed as the percentage of a public contract that needs to be offered as an extra-official payment in order to guarantee that the contract is awarded, ranges from 0 to $30 \%$ and averages just above $2 \%$. In terms of the percentage of time from a senior manager that needs to be dedicated to dealing with public officials about the "application and interpretation of laws and regulations," the average firm in the sample spends more than $30 \%$ of working time annually. ${ }^{14}$ In terms of bribe avoidability., $88 \%$ of the answers indicate that bribes can rarely be avoided and in more than $50 \%$ of the cases, the value of the bribe it is not known in advance. ${ }^{15}$

A final interesting question concerns how these various dimensions of corruption relate to each other. There is nothing surprising in the pattern of correlations among firm characteristics: older firms are more likely to be large, export more, and have some degree of foreign ownership. More interesting is that most of these features

the correct treatment, without having to make any extra-official payments?" The question about bribe uncertainty was phrased: "how often is it true that firms in your industry know in advance exactly how much the necessary extra-official payments will be?" Both set of answers were coded on a 1 ("always") to 6 ("never") scale.

${ }^{14}$ When asked about the exact monetary values of bribes for each of these items, the majority of respondents declined to answer. This is in part because the interviewees were invariably CEOs and these bribes are dealt with by different parts of the firm (telephone, taxes, licenses, imports, government contracts and general legal issues).

${ }^{15}$ Regarding bribe frequency, it ranges from about $5 \%$ of the firms having to pay bribes for electricity and telephone services, to almost $20 \%$ of them having to bribe to guarantee a government contract. 
are not systematically related to the various corruption characteristics - bribe size, frequency and uncertainty - with the exception of foreign-owned firms (which seem less likely to pay bribes and be often asked for bribes.) The pair-wise correlations between bribe magnitude and avoidability. are low. At the lower end, .02 is the correlation between bribe value uncertainty and percentage of the government contract paid as bribe, while at the other extreme, 30 is the correlation between percentage of government contract and share of managerial time spent dealing with public officials. The correlations between frequency and avoidability. features are similarly low (all at or below .3): reassuringly they tend to be negative between frequency and uncertainty. Thus, the less frequent the bribe, the less certain the firm is about its value but the correlation between frequency and avoidability. is positive, implying that the less often bribes are demanded, the more it is that likely they can be avoided. The pairwise correlations between bribe cost in terms of management time and bribe frequency tends to be very low (all below .15) but that is not the case for those between bribe frequency and share of government contract. They range, in the latter case, from a lowest value of .03 for electricity and phone services to a highest value of -.44 for taxes, this being above -. 3 for licences and dealings with the judiciary. Finally, it should be noted that although the correlation between the two measures of avoidability. and magnitude tend to be low, respectively (-.22 and 0.8), the same is not true for the correlation among some bribe frequency measures. In particular, it is above .5 for the correlation between the frequency of bribes for dealings with the judiciary, and for dealings regarding taxes and import licenses. Also above .5 is the simple correlation between bribe frequency for taxes and that for licenses (.68)

\section{$5 \quad$ Econometric results}

The objective of this section is to report the econometric findings concerning the effects of different aspects of corruption (bribe magnitude, frequency and avoidability.) on firm performance. The theoretical framework and the empirical evidence presented above suggest some hypothesis concerning the relationship between firm performance and corruption. If corruption is indeed an effective barrier that deters potential entrants, we would expect it to generate rents to incumbents. A sounder system of corruption will be associated with higher barriers, and therefore greater rents, potentially trickling down to incumbent firms in terms of profits, sales, and employment.

Our preferred measure of firm performance is job creation or employment growth. The careful choice of industrial sectors (firms operating in the more mature technology and formal sectors of the textiles and electronics industries) underlies employment growth as a reliable and comparable measure of performance. Moreover, measurement error is potentially reduced by focusing on growth of employment rather than value added or productivity (see Alterido et al., 2007, Fisman and Svensson, 2007). This 
choice is also partly justified on the basis of data constraints. Firms were informed that they were being sampled on the basis of their size (number of workers), so they felt at ease in disclosing this information, but less so with output, sales, capital, advertising and research and development expenditures. For example, 97 respondents disclosed the number of full time workers in 2005 while only 65 did the same for the value of output. This maps into having only 45 observations if output is used instead of employment in the bribe unavoidability specification below.

We therefore assess the effect of corruption on job creation, using as dependant variables the rate of change of employment from 2000 to 2005. In table 2, we describe the main variables used in the subsequent analysis. In table 3 we present the baseline model where job creation is regressed against a set of variables reflecting various different corruption features, namely frequency, uncertainty and magnitude of bribes. The set of controls include: initial size (number of full time workers in 2000), a dummy variable for industrial sector (which takes the value of 1 for textile firms, and zero for electronics), the age of the firm (in years since starting operation in one of these two sectors), whether or not the firm is foreign-owned, exports, and supplies the government.

Table 3 shows that the coefficient on bribe unavoidability is positive and significant while the coefficient on bribe uncertainty is negative and nearly significant at the $5 \%$ level. As we saw in the model above, bribe unavoidability and certainty may well be positively related to performance. The model shows that this is an indirect effect of the capacity of levying bribes on firms, this capacity can result in a higher barrier to entry, in a smaller number of firms in the market and in higher profit for the firms. In contrast, Table 3 also shows that the magnitude of the bribe is not significantly related to firm performance, and this seems to be consistent with the hypothesis in our model that bribes are a fixed percentage of the profits but independent from the level of profits.

Table 4 displays the effect of frequency of the bribe on firms' outcome; in particular we show this effect for different sources of bribes. In 3 out of 6 cases this effect is positive and highly significant (Licence, Taxes, Judiciary); in one it is positive but not significant (Custom), and in the other two cases the sign is statistically indistinguishable from zero. This suggests a positive link between frequency and firms' performance. As we saw, the effect of frequency on performance can also be explained on the basis of our model; frequency reveals a higher effectiveness of the system in levying bribe and as a result fewer firms will be allowed into the market.

Moreover, as it can be seen from all specifications in tables 3 and 4, there are significant differences according to whether or not a firm is a government supplier (those that sell to the government tend to have worse performances). There seem to be no significant differences in terms of performance emanating from industrial sector, foreign ownership or exporting behavior. The coefficient on firm size is only 
significant at the $15 \%$ level. $^{16}$

In the baseline results, firm age is shown to be negatively related to performance suggesting that older firms may experience lower rates of employment growth, controlling for initial size. It might also be due to technological leapfrogging that newer firms enjoy. This finding is consistent with the life-cycle view of firm growth (Evans, 1987). Thus it is possible to argue that the fact that older and less efficient firms are still on the market could be a signal of the presence of protection and barriers to entry. It is therefore instructive to investigate further this issue to assess how the baseline results behave when accounting for the interactions between firm age and each individual corruption feature. Table 5 shows the baseline results, with the introduction of the interaction term between bribe uncertainty in unavoidability and magnitude with firm age. Interesting, from the column 1, we note that the terms interacting bribe unavoidability and age is positive and significant, and the term firm age becomes non-significant and actually changes its sign. This suggests that the age effect is only important for by firms for which the bribe is more unavoidable. In other words, older firms are less profitable only when an effective corruption system- i.e. a system where the bribe cannot be avoided- protects the incumbent firm from the competition. ${ }^{17}$ Table 6 shows the baseline results with interactions of bribe uncertainty and bribe magnitude with firm age. The main message is that the absence of bribe avoidability. seems to be the crucial feature, and more important than the uncertainty surrounding the value of the bribe, be it in terms of management time or in percentage of a government contract. ${ }^{18}$

\section{Conclusions}

This paper argues that an important, but to a large extent, ignored harmful effect of corruption is as a barrier to the creation of new firms. As such, corruption reduces the threat of potential competition. We present a simple model that articulates these ideas. In particular, it highlights that somewhat neglected aspects of corruption (namely bribe unavoidability and bribe uncertainty) may have first-order effects on the economic performance of firms. Our empirical evidence shows that incumbent

\footnotetext{
${ }^{16}$ To explore whether multicollinearity may be behind such result, we run the same specifications excluding the variables more highly correlated with size, namely age and export propensity. It is interesting to note that the exclusion of age seems to have little effect on the coefficient on firm size, while the exclusion of export propensity tends to make it statistically significant at conventional levels. These are available upon request.

${ }^{17}$ The effect of taxes and of licences/permits on performance vanishes with the inclusion of the respective interactions, but this seems to be an effect of multicollinearity.

${ }^{18}$ We have also tried to evaluate the robustness of the results above through instrumental variables. It was difficult, as usual, to find good instruments. Yet, we do find that with regional dummies and the excluded corruption features as instruments, all the results discussed above remain. These results are available upon request.
} 
firms, when asked about the relative importance of various barriers to entry, identify corruption as the most important one. We also find that different features of bribing activity are strongly associated with firm performance; in particular that frequency and uncertainty of corruption are related to performance while the size of the bribe is not.

\section{References}

\section{References}

[1] Acemoglu, D. and T. Verdier (1998), "Property Rights, Corruption and the Allocation of Talent: A General Equilibrium Approach", The Economic Journal, Vol. 108, No. 450 , pp. 1381-1403

[2] Ades, Alberto, and Rafael Di Tella. "Rents, Competition and Corruption." American Economic Review 89, no. 4 (September 1999): 982-994.

[3] Aidt, T. (2003). "Economic Analysis of Corruption: A Survey." Economic Journal 113: F632-F652.

[4] Aidt, T. (2009), "Corruption, Institutions and Economic Development", Oxford Review of Economic Policy 25: 271-291

[5] Aidt, T. and J. Dutta (2008), "Policy Compromises: Corruption and Regulation in a Democracy": Economics and Politics, 20(3), 335-60

[6] Aterido, R., Hallward-Driemeier, M. and C. Pagés (2007). "Investment Climate and Employment Growth: The Impact of Access to Finance, Corruption and Regulations across Firms," Bonn: IZA DP No. 3138.

[7] Banerjee A.V. (1997), "A Theory of Misgovernance", Quarterly Journal of Economics 1997 112:4, 1289-1332

[8] Bardhan, P. (1997). "Corruption and Development: A Review of Issues." Journal of Economic Literature 35, 1320-1346.

[9] Barron, P. and.B. Olken, (2009) "The Simple Economics of Extortion: Evidence from Trucking in Aceh" Journal of Political Economy 117 (3), pp. 417-252, June 2009.

[10] Bartelsman, E., Haltiwanger, J. and S. Scarpetta (2004), "Microeconomic evidence of creative destruction in industrial and developing countries," World Bank Policy Research Working Paper 3464. 
[11] Besley, Timothy and McLaren, John (1993), 'Taxes and bribery: the role of wage incentives' Economic Journal, vol. 103, pp. 119-41.

[12] Bliss, Christopher and Di Tella, Rafael. "Does Competition Kill Corruption?" Journal of Political Economy, October 1997, 105 (5), pp. 1001-23

[13] Carrillo, J.D.(2000) "Grafts, Bribes and the Practice of Corruption", Journal of Economics \& Management Strategy (2000), 9, 257-286

[14] De Soto, H. 1990, The Other Path: The Invisible Revolution in the Third World, New York, Harper.

[15] Djankov, S., R. La Porta, F. Lopez-de-Silanes and A. Shleifer (2002). "The Regulation of Entry," Quarterly Journal of Economics, 107, 1-37.

[16] Evans, D. S. (1987), "The Relationship between Firm Growth, Size and Age", Journal of Industrial Economics, 35, 567-81

[17] Goulder, L.H., I.W.H. Parry and D. Burtraw, "Revenue Raising Versus Other Approaches to Environmental Protections: The Critical significance of preexisting distortions", Rand Journal of Economics, 28(5), 708-31

[18] Fisman, R., and J. Svensson (2007). "Are Corruption and Taxation Really Harmful to Growth? Firm Level Evidence." Journal of Development Economics 83(1): $63-75$.

[19] Hindriks, J. M. Keen and A. Muthoo (1999), "Corruption, Extortion and Evasion", Journal of Public Economics, 395-430.

[20] Johnson, S., J. McMillan and C. Woodruff (2002), "Property Rights and Finance", American Economics Review, 92(5), 1335-1356

[21] Kaufman, D.A., A. Kraay and M. Mastruzzi (2005), "Governance matters IV: Governance Indicators for 1996 - 2004", World Bank Policy Research Working Paper Series No. 3630, Washington DC

[22] Klapper, L., Laeven, L. and R. Rajan (2006). "Entry regulation as a barrier to entrepreneurship," Journal of Financial Economics, vol. 82(3), pages 591-629, December.

[23] Leff, N. (1964), "Economic Development through Bureaucratic Corruption", American Behavioral Scientist, vol. 8, no. 3, pp. 8-14.

[24] Lui, F. (1985). "An Equilibrium Queuing Model of Bribery", Journal of Political Economy, vol. 93, number 4, pp. 760-781 
[25] Mauro, Paulo (1995). "Corruption and Growth", Quarterly Journal of Economics, 110, 681-712.

[26] Méon, P. and K. Sekkat (2005). "Does corruption grease or sand the wheels of growth?," Public Choice, vol. 122(1), pages 69-97, January

[27] Mookherjee, D. and Png, I. (1995). Corruptible law enforcers: how should they be compensated? Economic Journal 105, 145-159

[28] Moreira, M. (1999). "Estrangeiros em uma Economia Aberta: Impactos Recentes sobre a Produtividade, a Concentracao e o Comercio Exterior." In: Giambiagi, F. and M. Moreira (Eds.), A Economia Brasileira nos Anos 90. BNDES, Rio de Janeiro.

[29] Paldan, M. (2002), "The Cross Country Pattern of corruption: Economies, Culture and the Seesaw Dynamics", European Journal of Political Economy, 18, $215-40$

[30] Pande, R. (2008). "Understanding Political Corruption in Low Income Countries," in Schultz, T. and J. Strauss (Eds.) Handbook of Development Economics (Volume 4), Amsterdam: Elsevier.

[31] Shleifer, A. and R.W. Vishny, "Corruption", Quarterly Journal of Economics, $108,599-617$

[32] Razafindrakoto, M and F Roubaud (2010), "Are International Databases on Corruption Reliable? A Comparison of Expert Opinion Surveys and Household Surveys in Sub-Saharan Africa," World Development 38 (8): 1057-1069

[33] Rose-Ackerman, Susan (1975), 'The economics of corruption', Journal of Public Economics, vol. 4, pp. 187-203.

[34] Rose-Ackerman, S. (1998), "Corruption and Government: Causes, Consequences and Reform, Cambridge: CUP

[35] Svensson, J. (2003). "Who Must Pay Bribes and How Much? Evidence from a Cross Section of Firms." Quarterly Journal of Economics 118: 207-30.

[36] Svensson, J. (2005). "Eight Questions about Corruption." Journal of Economic Perspectives. 19: 19-42.

[37] Treisman, D. (2007), "What Have We Learned About the Causes of Corruption From Ten Years of Cross-National Empirical Research?" Annual Review of Political Science 2007, 10: 211-244. 
Table 1: Basic statistics

\begin{tabular}{llllll}
\hline \hline Variable & Mean & Std. Dev. & Min. & Max. & N \\
\hline Empl. Growth & 0.085 & 0.692 & -1.427 & 3.091 & 90 \\
Sector (textiles=1) & 0.714 & 0.454 & 0 & 1 & 98 \\
Firm Age & 29.67 & 28.146 & 3 & 133 & 97 \\
Foreign owned (yes=1) & 0.188 & 0.392 & 0 & 1 & 96 \\
Exporter (yes=1) & 0.24 & 0.429 & 0 & 1 & 96 \\
Govern. supplier (yes=1) & 0.337 & 0.475 & 0 & 1 & 95 \\
Initial firm size (FT, in log) & 3.642 & 2.083 & 0 & 9.903 & 95 \\
Bribe unavoidability & 4.974 & 1.556 & 1 & 7 & 77 \\
Bribes' value uncertainty & 3.124 & 2.131 & 1 & 7 & 89 \\
Bribe frequency regarding & & & & & \\
Phone/electricity & 0.042 & 0.201 & 0 & 7 & 96 \\
Licenses and permits & 0.219 & 0.784 & 0 & 7 & 96 \\
Taxes & 0.156 & 0.759 & 0 & 7 & 96 \\
Government contracts & 0.258 & 0.806 & 0 & 7 & 93 \\
Customs & 0.987 & 2.338 & 0 & 7 & 78 \\
Judiciary & 0.354 & 1.414 & 0 & 7 & 96 \\
Bribe magnitude regarding & & & & & \\
Management time & 37.809 & 33.816 & 0 & 100 & 89 \\
Percentage of contract & 2.195 & 4.564 & 0 & 30 & 82 \\
\hline
\end{tabular}


Table 2: Percentage of firms that identified the factor as the most important barrier to a firm that is considering to start producing (enter) in the sector (textiles or electronics)

\begin{tabular}{l|ccc}
\hline \hline & $\begin{array}{c}2005 \\
(\mathrm{n}=97)\end{array}$ & $\begin{array}{c}2000 \\
(\mathrm{n}=95)\end{array}$ & $\begin{array}{c}1995 \\
\mathrm{n}=79)\end{array}$ \\
\hline Item & & & \\
Corruption & 30.93 & 32.63 & 34.18 \\
Finance & 21.65 & 18.95 & 13.92 \\
Taxes & 14.30 & 11.58 & 10.12 \\
Policy uncertainty & 9.28 & 10.53 & 16.45 \\
Lack of skilled labour & 7.22 & 8.42 & 8.86 \\
Non-competitive practices & 5.15 & 6.32 & 5.06 \\
Crime & 3.09 & 2.11 & 1.27 \\
Infrastructure & 2.06 & 2.11 & 2.53 \\
Regulations & 2.06 & 1.05 & 1.27 \\
Organized crime (mafia) & 2.06 & 2.11 & 1.27 \\
Exchange rate instability & 1.03 & 2.11 & 2.53 \\
Judiciary & 1.02 & 1.05 & 1.27 \\
\hline Total & 99.85 & 98.97 & 98.73 \\
\hline \hline
\end{tabular}

Source: Authors' calculations.

Columns do no add to $100 \%$ because of rounding 
Table 3: Effect of Bribe Magnitude and Unavoidability on Firm Performance

(1)

(2)

(3)

(4)

\begin{tabular}{|c|c|c|c|c|}
\hline Sector $($ textiles $=1)$ & $\begin{array}{l}-0.158 \\
(0.168)\end{array}$ & $\begin{array}{l}-0.184 \\
(0.232)\end{array}$ & $\begin{array}{l}0.0276 \\
(0.142)\end{array}$ & $\begin{array}{l}-0.291 \\
(0.219)\end{array}$ \\
\hline Firm Age & $\begin{array}{l}-0.0100^{* *} \\
(0.00429)\end{array}$ & $\begin{array}{c}-0.0104^{* * *} \\
(0.00392)\end{array}$ & $\begin{array}{c}-0.00810^{* * *} \\
(0.00290)\end{array}$ & $\begin{array}{r}-0.0162^{* * *} \\
(0.00536)\end{array}$ \\
\hline Foreign owned (yes=1) & $\begin{array}{c}0.302 \\
(0.200)\end{array}$ & $\begin{array}{r}-0.0279 \\
(0.186)\end{array}$ & $\begin{array}{l}-0.0305 \\
(0.178)\end{array}$ & $\begin{array}{l}-0.204 \\
(0.265)\end{array}$ \\
\hline Exporter $($ yes $=1)$ & $\begin{array}{l}-0.0533 \\
(0.227)\end{array}$ & $\begin{array}{c}-0.00621 \\
(0.266)\end{array}$ & $\begin{array}{l}-0.141 \\
(0.216)\end{array}$ & $\begin{array}{l}-0.156 \\
(0.276)\end{array}$ \\
\hline Govern. supplier (yes=1) & $\begin{array}{r}-0.275^{*} \\
(0.151)\end{array}$ & $\begin{array}{l}-0.310 \\
(0.205)\end{array}$ & $\begin{array}{r}-0.0880 \\
(0.123)\end{array}$ & $\begin{array}{c}-0.462^{* *} \\
(0.204)\end{array}$ \\
\hline Initial firm size (FT, in log) & $\begin{array}{c}0.0681 \\
(0.0809)\end{array}$ & $\begin{array}{c}0.120 \\
(0.0771)\end{array}$ & $\begin{array}{c}0.113 \\
(0.0753)\end{array}$ & $\begin{array}{c}0.168^{*} \\
(0.0892)\end{array}$ \\
\hline Bribe unavoidability & $\begin{array}{l}0.102^{* *} \\
(0.0428)\end{array}$ & & & \\
\hline Bribes' value uncertainty & & $\begin{array}{l}-0.0637^{*} \\
(0.0380)\end{array}$ & & \\
\hline $\begin{array}{l}\text { Bribe magnitude in terms } \\
\text { Management time }\end{array}$ & & & $\begin{array}{c}0.00418 \\
(0.00306)\end{array}$ & \\
\hline Percentage of contract & & & & $\begin{array}{c}0.0109 \\
(0.0150)\end{array}$ \\
\hline Constant & $\begin{array}{l}-0.253 \\
(0.289)\end{array}$ & $\begin{array}{c}0.367 \\
(0.286)\end{array}$ & $\begin{array}{l}-0.231 \\
(0.273)\end{array}$ & $\begin{array}{c}0.318 \\
(0.283)\end{array}$ \\
\hline Observations & 67 & 77 & 77 & 71 \\
\hline$R^{2}$ & 0.202 & 0.205 & 0.169 & 0.237 \\
\hline
\end{tabular}


Table 4: Effect of Bribes' Frequency on Firm Performance

\begin{tabular}{|c|c|c|c|c|c|c|}
\hline & (1) & $(2)$ & (3) & (4) & $(5)$ & (6) \\
\hline $\begin{array}{l}\text { Sector } \\
(\text { textiles=1) }\end{array}$ & $\begin{array}{l}-0.241 \\
(0.213)\end{array}$ & $\begin{array}{l}-0.251 \\
(0.212)\end{array}$ & $\begin{array}{l}-0.243 \\
(0.212)\end{array}$ & $\begin{array}{l}-0.266 \\
(0.213)\end{array}$ & $\begin{array}{l}-0.413 \\
(0.272)\end{array}$ & $\begin{array}{l}-0.310 \\
(0.216)\end{array}$ \\
\hline Firm Age & $\begin{array}{c}-0.0110^{* * *} \\
(0.00398)\end{array}$ & $\begin{array}{c}-0.0112^{* * *} \\
(0.00396)\end{array}$ & $\begin{array}{c}-0.0111^{* * *} \\
(0.00395)\end{array}$ & $\begin{array}{c}-0.0112^{* * * *} \\
(0.00406)\end{array}$ & $\begin{array}{c}-0.00927^{* *} \\
(0.00439)\end{array}$ & $\begin{array}{c}-0.0107^{* * *} \\
(0.00395)\end{array}$ \\
\hline $\begin{array}{l}\text { Foreign owned } \\
(\text { yes }=1)\end{array}$ & $\begin{array}{c}-0.00124 \\
(0.208)\end{array}$ & $\begin{array}{r}-0.0505 \\
(0.172)\end{array}$ & $\begin{array}{r}-0.0342 \\
(0.171)\end{array}$ & $\begin{array}{r}-0.0276 \\
(0.210)\end{array}$ & $\begin{array}{l}-0.238 \\
(0.300)\end{array}$ & $\begin{array}{r}-0.0387 \\
(0.177)\end{array}$ \\
\hline $\begin{array}{l}\text { Exporter } \\
(\text { yes }=1)\end{array}$ & $\begin{array}{r}-0.0170 \\
(0.266)\end{array}$ & $\begin{array}{r}-0.0247 \\
(0.263)\end{array}$ & $\begin{array}{r}-0.0138 \\
(0.264)\end{array}$ & $\begin{array}{r}-0.0421 \\
(0.293)\end{array}$ & $\begin{array}{l}0.0282 \\
(0.272)\end{array}$ & $\begin{array}{r}-0.0506 \\
(0.263)\end{array}$ \\
\hline $\begin{array}{l}\text { Governmnent } \\
\text { supplier }(\text { yes }=1)\end{array}$ & $\begin{array}{l}-0.374^{*} \\
(0.195)\end{array}$ & $\begin{array}{l}-0.372^{*} \\
(0.193)\end{array}$ & $\begin{array}{r}-0.369^{*} \\
(0.194)\end{array}$ & $\begin{array}{r}-0.364^{*} \\
(0.207)\end{array}$ & $\begin{array}{c}-0.539^{* *} \\
(0.249)\end{array}$ & $\begin{array}{c}-0.403^{* *} \\
(0.194)\end{array}$ \\
\hline $\begin{array}{l}\text { Initial firm size } \\
\text { (FT, in log) }\end{array}$ & $\begin{array}{c}0.110 \\
(0.0769)\end{array}$ & $\begin{array}{c}0.118 \\
(0.0751)\end{array}$ & $\begin{array}{c}0.114 \\
(0.0749)\end{array}$ & $\begin{array}{c}0.125 \\
(0.0758)\end{array}$ & $\begin{array}{c}0.132 \\
(0.0917)\end{array}$ & $\begin{array}{c}0.130^{*} \\
(0.0764)\end{array}$ \\
\hline \multicolumn{7}{|c|}{ Bribe frequency regarding } \\
\hline $\begin{array}{l}\text { Phone/ } \\
\text { electricity }\end{array}$ & $\begin{array}{l}-0.0117 \\
(0.178)\end{array}$ & & & & & \\
\hline $\begin{array}{l}\text { Licenses and } \\
\text { permits }\end{array}$ & & $\begin{array}{c}0.0955^{* * *} \\
(0.0326)\end{array}$ & & & & \\
\hline Taxes & & & $\begin{array}{c}0.0801^{* * *} \\
(0.0212)\end{array}$ & & & \\
\hline $\begin{array}{l}\text { Government } \\
\text { contracts }\end{array}$ & & & & $\begin{array}{l}0.0592 \\
(0.187)\end{array}$ & & \\
\hline Customs & & & & & $\begin{array}{c}0.0560 \\
(0.0356)\end{array}$ & \\
\hline Judiciary & & & & & & $\begin{array}{c}0.0948^{* * *} \\
(0.0301)\end{array}$ \\
\hline Constant & $\begin{array}{c}0.317 \\
(0.279)\end{array}$ & $\begin{array}{c}0.286 \\
(0.274)\end{array}$ & $\begin{array}{c}0.295 \\
(0.274)\end{array}$ & $\begin{array}{c}0.263 \\
(0.270)\end{array}$ & $\begin{array}{c}0.296 \\
(0.338)\end{array}$ & $\begin{array}{c}0.275 \\
(0.270)\end{array}$ \\
\hline Observations & 83 & 83 & 83 & 80 & 69 & 83 \\
\hline$R^{2}$ & 0.177 & 0.189 & 0.185 & 0.183 & 0.217 & 0.206 \\
\hline
\end{tabular}


Table 5: Age Interactions and The Impact of the Bribe Unavoidability on Firm Performance

\begin{tabular}{|c|c|c|c|c|}
\hline & $(1)$ & $(2)$ & $(3)$ & $(4)$ \\
\hline Sector $($ textiles $=1)$ & $\begin{array}{l}-0.160 \\
(0.178)\end{array}$ & $\begin{array}{l}-0.175 \\
(0.238)\end{array}$ & $\begin{array}{l}0.0235 \\
(0.144)\end{array}$ & $\begin{array}{l}-0.362 \\
(0.233)\end{array}$ \\
\hline Firm Age & $\begin{array}{c}0.00243 \\
(0.00436)\end{array}$ & $\begin{array}{r}-0.0115^{* *} \\
(0.00521)\end{array}$ & $\begin{array}{l}-0.00619 \\
(0.00390)\end{array}$ & $\begin{array}{r}-0.0129^{* *} \\
(0.00549)\end{array}$ \\
\hline Foreign owned (yes=1) & $\begin{array}{c}0.288 \\
(0.196)\end{array}$ & $\begin{array}{r}-0.0163 \\
(0.197)\end{array}$ & $\begin{array}{c}-0.00270 \\
(0.168)\end{array}$ & $\begin{array}{l}-0.307 \\
(0.304)\end{array}$ \\
\hline Exporter $($ yes $=1)$ & $\begin{array}{l}-0.107 \\
(0.234)\end{array}$ & $\begin{array}{c}-0.00461 \\
(0.266)\end{array}$ & $\begin{array}{l}-0.143 \\
(0.217)\end{array}$ & $\begin{array}{l}-0.169 \\
(0.279)\end{array}$ \\
\hline Govern. supplier $($ yes $=1)$ & $\begin{array}{l}-0.249 \\
(0.164)\end{array}$ & $\begin{array}{l}-0.293 \\
(0.217)\end{array}$ & $\begin{array}{r}-0.0784 \\
(0.125)\end{array}$ & $\begin{array}{c}-0.500^{* *} \\
(0.211)\end{array}$ \\
\hline Initial firm size (FT, in log) & $\begin{array}{c}0.0786 \\
(0.0822)\end{array}$ & $\begin{array}{c}0.118 \\
(0.0775)\end{array}$ & $\begin{array}{c}0.111 \\
(0.0739)\end{array}$ & $\begin{array}{c}0.171^{*} \\
(0.0892)\end{array}$ \\
\hline Bribe unavoidability & $\begin{array}{c}0.191^{* * *} \\
(0.0576)\end{array}$ & & & \\
\hline Bribes' value uncertainty & & $\begin{array}{l}-0.0770 \\
(0.0621)\end{array}$ & & \\
\hline $\begin{array}{l}\text { Bribe magnitude in terms of: } \\
\text { Management time }\end{array}$ & & & $\begin{array}{c}0.00553 \\
(0.00471)\end{array}$ & \\
\hline Percentage of contract & & & & $\begin{array}{c}0.104 \\
(0.0869)\end{array}$ \\
\hline $\begin{array}{l}\text { Interaction age and } \\
\text { Bribe features }\end{array}$ & $\begin{array}{c}-0.00264^{* *} \\
(0.00115)\end{array}$ & $\begin{array}{l}0.000414 \\
(0.00121)\end{array}$ & $\begin{array}{l}-6.05 \mathrm{e}-05 \\
(9.89 \mathrm{e}-05)\end{array}$ & $\begin{array}{l}-0.00172 \\
(0.00155)\end{array}$ \\
\hline Constant & $\begin{array}{c}-0.729 * * \\
(0.355)\end{array}$ & $\begin{array}{c}0.391 \\
(0.300)\end{array}$ & $\begin{array}{l}-0.277 \\
(0.308)\end{array}$ & $\begin{array}{c}0.224 \\
(0.295)\end{array}$ \\
\hline Observations & 67 & 77 & 77 & 71 \\
\hline$R^{2}$ & 0.234 & 0.205 & 0.173 & 0.246 \\
\hline
\end{tabular}


Table 6: Interactions and The Impact of the Bribe frequency on Firm Performance
(1)
(2)
(3)
(4)
(5)

(6)

\begin{tabular}{|c|c|c|c|c|c|c|}
\hline $\begin{array}{l}\text { Sector } \\
(\text { textiles }=1)\end{array}$ & $\begin{array}{l}-0.242 \\
(0.213)\end{array}$ & $\begin{array}{l}-0.250 \\
(0.213)\end{array}$ & $\begin{array}{l}-0.241 \\
(0.213)\end{array}$ & $\begin{array}{l}-0.293 \\
(0.215)\end{array}$ & $\begin{array}{l}-0.442 \\
(0.272)\end{array}$ & $\begin{array}{l}-0.312 \\
(0.218)\end{array}$ \\
\hline Firm Age & $\begin{array}{c}-0.0109^{* * *} \\
(0.00413)\end{array}$ & $\begin{array}{c}-0.0111^{* *} \\
(0.00450)\end{array}$ & $\begin{array}{c}-0.0109^{* * *} \\
(0.00411)\end{array}$ & $\begin{array}{c}-0.00988^{* *} \\
(0.00420)\end{array}$ & $\begin{array}{c}-0.00882^{* *} \\
(0.00435)\end{array}$ & $\begin{array}{r}-0.0107^{* * *} \\
(0.00398)\end{array}$ \\
\hline $\begin{array}{l}\text { Foreign owned } \\
(\text { yes }=1)\end{array}$ & $\begin{array}{c}0.00423 \\
(0.215)\end{array}$ & $\begin{array}{r}-0.0417 \\
(0.183)\end{array}$ & $\begin{array}{c}-0.0193 \\
(0.175)\end{array}$ & $\begin{array}{r}-0.0169 \\
(0.203)\end{array}$ & $\begin{array}{l}-0.239 \\
(0.307)\end{array}$ & $\begin{array}{c}-0.00757 \\
(0.176)\end{array}$ \\
\hline $\begin{array}{l}\text { Exporter } \\
(\text { yes }=1)\end{array}$ & $\begin{array}{c}-0.0183 \\
(0.268)\end{array}$ & $\begin{array}{c}-0.0184 \\
(0.284)\end{array}$ & $\begin{array}{c}-0.00348 \\
(0.273)\end{array}$ & $\begin{array}{r}-0.0328 \\
(0.293)\end{array}$ & $\begin{array}{l}0.0725 \\
(0.268)\end{array}$ & $\begin{array}{l}-0.0486 \\
(0.265)\end{array}$ \\
\hline $\begin{array}{l}\text { Governmnent } \\
\text { supplier }(\text { yes }=1)\end{array}$ & $\begin{array}{l}-0.374^{*} \\
(0.196)\end{array}$ & $\begin{array}{l}-0.375^{*} \\
(0.195)\end{array}$ & $\begin{array}{l}-0.370^{*} \\
(0.195)\end{array}$ & $\begin{array}{l}-0.400^{*} \\
(0.205)\end{array}$ & $\begin{array}{c}-0.618^{* *} \\
(0.260)\end{array}$ & $\begin{array}{c}-0.410^{* *} \\
(0.196)\end{array}$ \\
\hline $\begin{array}{l}\text { Initial firm size } \\
(\mathrm{FT}, \text { in } \log )\end{array}$ & $\begin{array}{c}0.109 \\
(0.0782)\end{array}$ & $\begin{array}{c}0.117 \\
(0.0784)\end{array}$ & $\begin{array}{c}0.111 \\
(0.0777)\end{array}$ & $\begin{array}{c}0.122 \\
(0.0771)\end{array}$ & $\begin{array}{c}0.140 \\
(0.0953)\end{array}$ & $\begin{array}{c}0.129^{*} \\
(0.0773)\end{array}$ \\
\hline $\begin{array}{l}\text { Phone/ } \\
\text { electricity }\end{array}$ & $\begin{array}{l}0.0634 \\
(0.158)\end{array}$ & & & & & \\
\hline $\begin{array}{l}\text { Licenses and } \\
\text { permits }\end{array}$ & & $\begin{array}{c}0.111 \\
(0.0895)\end{array}$ & & & & \\
\hline Taxes & & & $\begin{array}{c}0.139 \\
(0.0990)\end{array}$ & & & \\
\hline $\begin{array}{l}\text { Government } \\
\text { contracts }\end{array}$ & & & & $\begin{array}{c}0.451 \\
(0.276)\end{array}$ & & \\
\hline Customs & & & & & $\begin{array}{l}0.149^{* *} \\
(0.0621)\end{array}$ & \\
\hline Judiciary & & & & & & $\begin{array}{l}0.127^{* *} \\
(0.0534)\end{array}$ \\
\hline $\begin{array}{l}\text { Interaction age } \\
\text { Bribe features }\end{array}$ & $\begin{array}{l}-0.00268 \\
(0.00485)\end{array}$ & $\begin{array}{r}-0.000767 \\
(0.00408)\end{array}$ & $\begin{array}{l}-0.00295 \\
(0.00519)\end{array}$ & $\begin{array}{l}-0.0148^{* *} \\
(0.00592)\end{array}$ & $\begin{array}{c}-0.00774^{* *} \\
(0.00386)\end{array}$ & $\begin{array}{l}-0.00454 \\
(0.00595)\end{array}$ \\
\hline Constant & $\begin{array}{c}0.318 \\
(0.280)\end{array}$ & $\begin{array}{c}0.285 \\
(0.276)\end{array}$ & $\begin{array}{c}0.297 \\
(0.276)\end{array}$ & $\begin{array}{c}0.264 \\
(0.269)\end{array}$ & $\begin{array}{c}0.295 \\
(0.336)\end{array}$ & $\begin{array}{c}0.281 \\
(0.273)\end{array}$ \\
\hline $\begin{array}{l}\text { Observations } \\
R^{2}\end{array}$ & $\begin{array}{c}83 \\
0.177\end{array}$ & $\begin{array}{c}83 \\
0.189\end{array}$ & $\begin{array}{c}83 \\
0.186\end{array}$ & $\begin{array}{c}80 \\
0.205\end{array}$ & $\begin{array}{c}69 \\
0.241\end{array}$ & $\begin{array}{c}83 \\
0.207\end{array}$ \\
\hline
\end{tabular}

